Religion and Gender vol. 1, no. 1 (2011), 1-17

www.religionandgender.org

URN: NBN:NL:UI:10-1-101587

ISSN: $1878-5417$

Publisher: Igitur Publishing (Utrecht)

Copyright: this work is licensed under a Creative

Commons Attribution License (3.0)

\title{
Openings: A Genealogical Introduction to Religion and Gender
}

ANNE-MARIE KORTE

\section{Profile Statement}

Religion and Gender is the first refereed online international journal for the systematic study of gender and religion in an interdisciplinary perspective. The journal explores the relation, confrontation and intersection of gender and religion, taking into account the multiple and changing manifestations of religion in diverse social and cultural contexts. It analyses and reflects critically on gender in its interpretative and imaginative dimensions and as a fundamental principle of social ordering. It seeks to investigate gender at the intersection of feminist, sexuality, queer, masculinity and diversity studies.

As an academic journal, Religion and Gender aims to publish high level contributions from the humanities and from qualitative and conceptual studies in the social sciences. It wants to focus in particular on contemporary debates and topics of emerging interest. Albeit international in scope, the journal takes seriously that it is situated in contemporary Europe. It seeks to reflect on this position, particularly from postmodern, postcolonial, and post-secular perspectives. 
The journal appears twice a year, each issue focussing on a specific theme. Scholars are welcome to submit articles for review or propose topical issues under their guest editorship. Renowned scholars may be invited to submit keynote articles on specific topics. In particular, we welcome contributions which advance, broaden and innovate discourses, debates and paradigms by virtue of their originality, rigour and/or counterhegemonial perspectives. All articles will be internationally refereed.

The editorial board of Religion and Gender also welcomes book reviews, comments, literature surveys, concise discussion papers, and announcements of academic events, academic networks, new publications, and relevant mailing lists.

The appearance or 'coming out' of this first issue of Religion and Gender is not a deus or dea ex machina at all. This new online journal has actually had many beginnings, inspired and passionate as well as ordinary and practical in kind, and it already knows some endings too. Four intensive years of preparation have come to a close with the actual publication of Religion and Gender. At least now we as the birth-giving editorial team know how to start an academic open access journal. If only we had this crucial expertise right from the beginning!

To recall some of the openings involved in the start of this journal seems a telling way to present its position and profile. This first editorial, therefore, will be introductory by way of a genealogy which identifies some founding moments and substantial debates leading to the creation of this journal. It will also give an introduction to the contributions in this first issue.

\section{Religion and Gender as Portal}

In hindsight, a firm and decisive beginning of this journal lies in its naming. From the outset, it was clear to all the initiating editors, coming from such disciplines as cultural anthropology, theology, religious studies, philosophy, cultural studies and gender studies, and rooted in various European academic traditions, that it should be called Religion and Gender. This pair of key terms was able to bring us together as an executive editorial team from across quite different locations and disciplines, and it steered us in articulating our shared concerns and common intellectual interests. The two terms have become the centre of our profile statement: 'The journal explores the relation, confrontation and intersection of gender and religion, taking into account the multiple and changing manifestations of 
religion in diverse social and cultural contexts. It analyses and reflects critically on gender in its interpretative and imaginative dimensions and as a fundamental principle of social ordering. It seeks to investigate gender at the intersection of feminist, sexuality, queer, masculinity and diversity studies.'

As we were widening the international network around this journal, we found that the title of Religion and Gender also appealed to scholars of different generations and genders, and working in a broad spectrum of disciplines, studying various religions or religion-related phenomena, and employing a great variety of gender-sensitive approaches. During the period of formation of this journal, the appropriateness of this name never became a point of debate.

When asked to state their view on the goals and direction of this journal from their own position and academic specialization, many members of our advisory and editorial boards amended and augmented our working definitions of 'religion' and 'gender'. And they did so in a number of ways. They nuanced and layered these concepts, sharpened them and argued for unfolding them either historically or systematically. They pluralized them and urged to make them more fluid and encompassing. They illustrated the impact and the employability of these terms - as well as their limitations - in disciplines as diverse as comparative religion, practical theology, cultural analysis, anthropology of religion, Jewish, Islamic and Buddhist studies, masculinities studies, ethics and art history. They proposed theoretical frameworks considered most suitable to investigate topical topics of religion and gender, ranging from postmodern, postcolonial, post-secular, post-feminist and new-materialist approaches to the philosophy of science, comparative history, biographical and narrative enquiry, critical discourse analysis and visual hermeneutics. They insisted on using and revising the concepts of religion and gender in the light of the fast social and cultural changes in our globalized world and the need to incorporate these dynamics in our often rigid academic institutions. Many of them expressed the hope that working in interdisciplinarity at the crossroads of religion and gender would help open up the compartmentalization and hyperspecialization of academic 'monodisciplining'. In particular the need to cross and problematize the 'modern' and tenacious boundaries between theology, religious studies and 'secular' sciences was put forward.

Remarkably, however, in all these statements the two core terms religion and gender, either separately or as a pair, never became disputed. So, we may wonder, what makes this couple of key terms, which already 
has a distinct history in this field of studies since the mid-nineties, equally relevant to the present and the future of this field? Why is precisely this combination of catchwords, at this very moment, capable of bringing together researchers from such a variety of academic disciplines and scholarly interests?

The idea that sparked us was to set up an academic journal for the systematic study of gender and religion in an interdisciplinary perspective, based in the humanities and in qualitative and conceptual studies in the social sciences. According to us, only a broadly-based journal like this would be able to answer the need to assemble and rearrange the many present-day disciplinary approaches that zoom in at issues associated with 'religion and gender'. It is a fact that the field of studies in religion and gender - ranging from investigating the position and perception of women within both established and upcoming religious communities to examining the significance of gender approaches for the deconstruction of the religion/secularity distinction - has been 'discovered' during the last decade by a growing number of scholars in the humanities and the social sciences. ${ }^{1}$ New or expanding scholarly interest in these issues has emerged within scientific domains and from vantage points that do not only or primarily belong to theology and religious studies, the disciplines that have initiated and harboured this type of research from the last quarter of the 20 th century. ${ }^{2}$ The past few years have also seen an increasing number of

1 See a.o. S. Mahmood, Politics of Piety: The Islamic Revival and The Feminist Subject, Princeton, NJ: Princeton University Press 2005; S. M. Chewning (ed.), Intersections of Sexuality and the Divine in Medieval Culture: The Word Made Flesh, Aldershot: Ashgate 2005; L. Deeb, An Enchanted Modern: Gender and Public Piety in Shi'i Lebanon, Princeton/Oxford: Princeton University Press 2006; K. M. Morin and J. Kay Guelke (eds.), Women, Religion \& Space: Global Perspectives on Gender and Faith, Syracuse NY: Syracuse University Press 2007; R. Braidotti, 'In Spite of the Times. The Postsecular Turn in Feminism' in Theory, Culture \& Society 25:6 (2008), 1-24; S. Bracke, 'Conjugating the Modern/Religious, Conceptualizing Female Religious Agency. Contours of a 'Postsecular' Conjuncture' in Theory, Culture \& Society 25:6 (2008), 51-67; K. Aune, S. Sharma and G. Vincett (eds.), Women and Religion in the West: Challenging Secularization, Aldershot: Ashgate 2008; J. R. Jakobsen and A. Pellegrini (eds.), Secularisms, Durham/London: Duke University Press 2008.

2 For recent overviews of gender studies in theology and religious studies see a.o. R. R. Ruether (ed.), Feminist Theologies: Legacy and Prospect, Minneapolis: Fortress Press, 2007; M. Kamitsuka, Feminist Theology and The Challenge of Difference, Oxford: Oxford University Press 2007; C. Keller, 'The Apophasis of Gender: A Fourfold Unsaying of Feminist Theology' in Journal of the American Academy of Religion 76:4 (2008), 905933; G. Howie and J. Jobling (eds.), Women and the Divine: Touching Transcendence, New York: Palgrave Macmillan 2008; L. Isherwood and K. McPhilips (eds.), PostChristian Feminism: A Critical Approach. Aldershot: Ashgate 2008; P. S. Anderson (ed.), 
academic conferences, special issues of journals and newly designed courses devoted to the topic of religion and gender, again within a great variety of academic disciplines and often according to interdisciplinary arrangements. 'Religion', as it has been noticed, rediscovered and reinvented as part of contemporary scholarly agendas for the greater part because of its increased visibility and huge political impact since 9/11 and its aftermath, seems to lend itself well to be studied in a pair with 'gender'. But what exactly is the focus here? Is this striking attention for 'religion and gender' more than an upsurge of interest, an intuitive reaction evoked by economically, politically and culturally rapidly changing and colliding life patterns worldwide?

Acknowledging the deep challenge that is posed by these new interests and sensibilities, and noticing the demand for confrontation, interlocution and collaboration that they entail for us as specialists in this area, we envisioned a capacious scholarly forum of exchange, directed at 'the systematic study of religion and gender in an interdisciplinary perspective'. From the very beginning of setting up this journal we were aware that to realize this goal, we had to find a common ground and a shared focus to navigate and determine our course in this complex and fast expanding area of studies. - Or had we better leave behind this twodimensional metaphor of territoriality and foundations and speak of constituting common access, shared gateways, and clearly marked interactive meeting spaces? Anyway, and simply put, the search itself for a common ground and a shared focus could be called the actual reason for establishing this journal. Indeed, where else to discuss the complicating role of gender as an analytical category in this growing and broadening academic interest in religion? And with whom else to debate its

New Topics in Feminist Philosophy of Religion: Contestations and Transcendence Incarnate, Amsterdam/New York: Springer Press 2009; L. Sjorup and H. Romer Christensen (eds.), Pieties and Gender, Leiden: Brill 2009; S. Briggs and M. McClintock Fulkerson (eds.), Oxford Handbook of Feminist Theology, Oxford: Oxford University Press 2011. Where gender studies in religion and theology for a long time have focused on women, there is an emerging interest in men and masculinity, as is demonstrated in B. Krondorfer (ed.), Men and Masculinities in Christianity and Judaism, London: SCM Press 2009. Another widening of the field is the recent interest in queer perspectives on gender and sexuality in religion and theology, such as in M. Althaus-Reid, The Queer God, London/New York: Routledge 2003; G. Loughlin (ed.), Queer Theology: Rethinking the Western Body, Malden/Oxford: Blackwell 2007; M. M. Wilcox, Queer Women and Religious Individualism, Bloomington: Indiana University Press 2009; K. Browne, S. R. Munt and A. K. T. Yip (eds.), Queer Spiritual Spaces: Sexuality and Sacred Spaces, Farnham/Burlington: Ashgate 2010. 
counterpart, the complicating role of the (self-)critical study of religion(s) for feminist scholarship and its current proliferation in gender, sexuality, queer, masculinity and diversity studies?

Thus the title Religion and Gender, in our view, points to the creation of a much needed broadly-based forum of debate in which interests and concerns as the aforementioned can be articulated, exchanged and elaborated. For several reasons, we think that Religion and Gender will continue to be productive and sustainable, and will be acting as a 'portal' for the type of exchange and debate we envision.

Firstly, the fact that the combination of the key words 'religion and gender' has played a crucial role in transforming and reorganizing this field of studies in the past decades is an indication of its potential. Coined in the mid-nineties to join forces when feminist studies on a large scale turned into gender studies and claimed their own space and legitimacy in mainstream academics, the title Religion and Gender has made more visible and academically challenging the research questions and aspirations that were engendered and promoted by feminist theology and women's studies in religion(s). ${ }^{3}$ This (re)assembling and transformative capacity of the key terms religion and gender seems an important heritage to build on.

Secondly, the heading Religion and Gender and its focus as proposed and outlined above, indicate that this journal parallels other significant attempts to reorganize the discussions in the field of religion. In negotiating secularization and globalization the academic study of religion has undergone radical changes in the past two decades. The traditional hegemony of (Christian) theology and the classic science of religion (derived from theology) has been seriously contested, and simultaneously religion(s) have become the object of study in a variety of academic disciplines in the humanities and social sciences. The recent emergence of interdisciplinary academic journals such as the Journal of Religion and

\footnotetext{
See U. King (ed.), Religion and Gender, Oxford: Blackwell 1995; E. Castelli (ed.), Women, Gender, Religion: A Reader, New York: Palgrave 2001; R. R. Ruether (ed.), Gender, Ethnicity and Religion: Views from the Other Side, Minneapolis: Fortress Press 2002; U. King and T. Beattie (eds.), Religion, Gender and Diversity: Cross-Cultural Perspectives, London: Continuum 2004; F. Uhl, A. R. Boelderl (eds.), Das Geschlecht der Religion, Berlin: Parerga 2005; S. Demel and R. Emig (eds.), Gender $\leftrightarrow$ Religion, Heidelberg: Universitätsverlag Winter 2008; A.-K. Höpflinger, A. Jeffers and D. Pezzoli-Olgiati (eds.), Handbuch Gender und Religion, Göttingen: Vandenhoeck \& Ruprecht 2008; H. Walz and D. Plüss (eds.), Theologie und Geschlecht: Dialoge Querbet, Berlin: Lit verlag 2008. For critical discussions on the rise of women's and gender studies as established academic disciplines see J. Wallach Scott (ed.), Women's Studies on the Edge, Durham/London: Duke University Press 2008.
} 
Popular Culture, Religion and Human Rights, Interdisciplinary Journal of Research on Religion, Material Religion, Politics and Religion, Journal of Race, Ethnicity and Religion and the Oxford Journal of Law and Religion, alongside Religion and Gender, signals a shift in the academic approach of religion. These new journals show an analogous search for a more topical rather than disciplinary approach, and attest to a growing common interest to (re)connect the study of religion to current social and political questions, moral concerns and lived spirituality.

Thirdly, the widespread public attention paid to 'issues' of religion and gender as markers of social conflict, cultural controversy and political contestation asks for the development of precise analytical instruments that are able to do justice to the intricacies of these phenomena. It is evident that in our postcolonial world and (post)secular Western societies, the profiling and identity politics of religions as well as the controversies about religion are often shaped by issues directly related to gender and sexuality. Gendered symbols like headscarves, beards, and female and male circumcision figure as signs of religious antagonism and incompatibility. That is to say, gender and sexuality form a main arena or battlefield of religion(s) in our modern world, not least in Western Europe. ${ }^{4}$ Against this background, it is urgent to explore the current major challenges for the study of religion and gender, to identify the fundamental critical issues, and to address them in innovative ways and from an interdisciplinary perspective, in order to break new ground in the understanding of the complex dynamics of religion and gender in our contemporary world.

We see religion and gender, our two key terms, as an eye-opener, capable of opening up new debates exactly because of their destabilizing, even 'troubling' references. Religion and gender have never been stable concepts and it is unlikely that they will become fixed or delineated soon, at least not in each other's vicinity. Both 'religion' and 'gender' are not static phenomena but are involved in ongoing and complex processes of change. This is particularly the case in the current globalizing world, where

4 See a.o. C. von Braun, G. Jähnert et al (eds.), 'Holy War' and Gender / 'Gotteskrieg' und Geschlecht: Violence in Religious Discourses / Gewaltdiskurse in der Religion, Berlin: Lit Verlag 2006; J. Wallach Scott, The Politics of the Veil, Princeton/Oxford: Princeton University Press 2007; H. Herzog and A. Braude (eds.), Gendering Religion and Politics: Untangling Modernities, New York: Palgrave MacMillan 2009; T. Dreher and C. Ho (eds.), Beyond the Hijab Debates: New Conversations on Gender, Race and Religion, Newcastle upon Tyne: Cambridge Scholars Publishing 2009; L. Martín Alcoff and J. D. Caputo (eds.), Feminism, Sexuality, and the Return of Religion, Bloomington: Indiana University Press 2011. 
religion and gender are manifested in multiple ways and becoming increasingly complicated. As a consequence, the study of religion and gender is a highly dynamic and fascinating enterprise.

\section{Open Access as Password}

A second important starting point lies in the decision to create an online and open access academic journal. Also at the very beginning we embraced the idea of 'direct publishing' and 'free entrance' that online and open access publishing brings about. 'Open access' - the magic word of this whole project, a real 'Open, Sesame'! - represents and materializes our stance on the accessibility and the social relevance of this journal, its visibility, its intermediary role in current and emerging debates, and its function in warranting the author's ownership of intellectual work as much as possible. But apart from the intention of honouring new debates, keeping short lines and fast tracks of publishing, and offering easy access to upcoming groups and new generations of scholars in our field, there are still some other good reasons to chose open access publication which are more intrinsically related to our subject of enquiry.

Open access publication, in our opinion, does not only refer to the scope, pace, and amount of exchange it brings forth, but also to the transparency and the quality of conversation that it can enable. Research into religion and gender is always 'entangled work', as it means engaging in conversations, both scholarly and otherwise, that are often already formed by deeply ingrained and lived notions (words, gestures, images) of what 'religion' is and is not, of what it does and can(not) do, and of what it should be or not be. We do not only speak about religion but religion also speaks by, for and against us. And, intriguing as it is complicating, the same could be said about gender. For this reason, contemporary and interdisciplinary research into religion and gender conducted by scholars who are often simultaneously witnesses to and participants in the subject they study, demands vigorous, well-informed, critical and self-critical debate. Open access publication can deliver important contributions to this debate by staging these conversations and opening them up for both insiders and outsiders.

And secondly, open access publication also addresses other and related epistemological and moral aspects of scholarship in both religion and gender studies, in particular the dynamics of distance and personal engagement that binds researchers to the topics, persons and communities they investigate. Open access publication, moreover, with its technologically organized promise of direct publishing and free entrance, 
intensifies the questions about locality and loyalty, privilege and marginalization, and objectivity and embodiment that gender studies has raised and put on the academic agenda. Open access publication has the paradoxical quality of recalling 'old' ideals of activist, engaged and grassroots scholarship, epitomized by the idea of immediate exchange between the researchers and the persons or groups they commit themselves to in their research. And at the same time it has the quality of meeting 'new' academic requirements of presenting our research results and demonstrating its relevance, not only to academic peers and funding instances but also as 'open' to wider audiences as contemporary media make feasible. As an upcoming ordering principle of academic publicity and communication, however, open access publication also raises firm questions about its organization and economic costs: who can be held responsible for granting - and paying - 'free entrance' and reaching 'the widest possible audience'? What if the authors whose work actually gets published are saddled with all the costs?

It is noteworthy that in their statements on the journal's position and preferred tasks, none of the members of our editorial network commented on our choice for open access publication. Its advantages were not mentioned, nor were its possible dangers. However, concern over the accessibility and social relevance of Religion and Gender is the most discussed subject in the statements of the editorial board members. The following quotation sums up the cry from the heart in many statements: 'A critical issue in the study of gender and religion is how to ensure that scholarship in this area feeds and is fed by movements of social change. ... It is important that critical studies at the intersection of religion and gender contribute to making the world a less unequal and violent place.' A number of authors warn that the striving after academic excellence and the embrace of sophisticated theory risk making us forget that our primary concern lies in our attentiveness to the social conflicts of religion and gender in daily life. They urge 'to recommit our scholarship to the pursuit of progressive visions of gender equality, sexual liberation, and economic as well as political justice.' Or, more evocatively put, they hope that Religion and Gender will 'offer an academic venue that does not limit itself to describing what is but sets out to envision what may become.'

However, the practical question of how to guarantee and implement these commitments is much less touched upon in these statements. One of the editorial board members signals, in an aside, the importance of facilitating concretely the 'paradigm shift' that gender studies implies, 'forging a fresh area of concern over the study of religion.' 
This means that a supporting infrastructure should be promoted, consisting of

professional organizations that give it legitimacy; innovators who introduce and advance the paradigm; educators who propagate the paradigm's ideas by passing them on to the student contingent; conferences that are devoted to discussing themes central to the paradigm; sources of funding for further research; and not least of all journals and editors who write about fresh systems of thought.

A few writers of statements mention the importance of staging and engaging in (self-)critical dialogue and conversation to break through hegemonic academic objectification and 'othering' in the study of religion(s). They advance the need of being exposed to 'marginalized views', 'critical voices' and 'other discourses/discourses of the Other'. As one of them writes:

We need to provide forums for dialogue and conversation that offer participants a chance to take risks and to render themselves vulnerable in the presence of the other. ... Such conversations must happen between feminists and critical men's scholars, postmodernists and political activists, Buddhists and Muslims, theoreticians and practitioners, Judith Butler and the Dalai Lama, Jewish and Christian women, scholars and policy makers, humanists and social scientists, historians and spiritual guides, and many more. The conversation partners should be willing to engage - and transcend - the binaries that separate us, whether male/female, gay/straight, heteronormative/queer, devout/secular, or spiritual/ empirical.

So how to engender an infrastructure of paradigm shift and critical practices of conversation? Open access publication, we hope, is one of the ways, and a very practical one indeed, to answer the appeal, so prominent among our board members, that Religion and Gender should consist of cutting-edge academic work that is above all socially relevant.

\section{(In)compatibilities: Critical Issues in the Interdisciplinary Study of Religion and Gender}

A third decisive start was the plan to open the journal with a discussion of the most critical issues for the study of religion and gender at this moment. In the first issue of the journal we wanted to provide the state of the art of the current study of religion and gender, to identify the most salient points of contemporary debate, and to present the challenges facing this field of studies. A grand opening! 
We embarked upon formulating the critical issues that have our common interest, across the borders of our different disciplines, and listed the top 5 of the editorial team:

How does the actual configuration of religion, particularly in contemporary Europe, question and challenge the basic concepts (and presuppositions) in the classic study of religion and gender?

How does the actual and new theorizing of materiality, nature, gender and embodiment question and challenge the basic concepts (and presuppositions) in the classic study of religion and gender?

What are the implications of queer theory for the study of religion and gender?

Why are the fields of embodiment, sexuality and gender the battlefields par excellence where the tensions between religion(s) and secularism are manifested in modern societies?

How do we relate actual scholarly-analytical approaches to the study of religion and gender with the political origins and edges of classic approaches of gender, sexuality and religion?

These questions are concrete examples of the kind of debates we want to further by founding an interdisciplinary journal for the systematic study of gender and religion. The search for a common ground and a shared focus as stated above takes shape in the identification of our serious concerns and the critical scholarly questions they raise, questions that need to be explored from the different angles and disciplines that meet in this journal. This forms the first route of practising our systematic interest. A second route is the explication, exploration and confrontation of the theoretical frameworks and methodological approaches that guide our research. Both itineraries have the above formulated type of questions as their point of departure.

In first instance, we imagined the first issue of Religion and Gender to consist of articles that would discuss each of these five core questions in a comprehensive and fundamental way, and we started looking for authors who would be able and willing to write these contributions. However, we had not yet fully acknowledged that an in-depth discussion of these critical issues also requires an interdisciplinary approach and setting from the 
outset. And although, according to us, interdisciplinarity does not follow by itself from the plurality of disciplines but depends on how their confrontation and their collaboration are organized, we do think that in any case the first step is to warrant the plurality and possible interaction of perspectives Once again, our primary aim is not to establish or broaden this plurality of disciplines and perspectives as such, because, as noted above, a wide-ranging scholarly interest in religion and gender has already manifested itself in recent years. Our goal is to create a forum for bringing together the interests and results from these different disciplines and stimulating the debate concerning the own research traditions and conventions of these fields. This is particularly important because of large differences, if not outright watersheds, existing between the disciplines and approaches that consider the study of religion and gender to belong on their agenda.

This means that one of the objectives of this journal is to promote the discussion both on and between the different disciplines that engage with religion and gender at the moment. So the interdisciplinarity we want to practise and further encompasses both the confrontation with the diversity of the existing scientific approaches to religion and gender and the explicit conversation about the particularity, differences and (in)compatibilities of these approaches. In the recent past, the perception of (in)compatibilities within the different approaches of religion and gender has been dominated by the emic-etic distinction and in particular by the insider-outsider paradigm regarding religious engagement, reflecting that this debate is largely constituted by an opposition between religious and secular stances and is part of discussions on the status and influence of Christianity and Judaism in modern Western societies. This opposition has gradually come under fire by the dismantling of the 'natural' relationship between modernity and secularism. Yet there are more incompatibilities, and of a different nature, that affect our interdisciplinary scholarly agendas and need to be acknowledged and discussed, such as those between feminist and non- or post-feminist approaches, and between highly theoryladen and practical or activist forms of scholarship. And above all we need to acknowledge our own various but often not explicated understandings of 'religion', since this creates one of the most stubborn and unrecognized incompatibilities of interdisciplinary research in religion and gender.

These findings and insights into the interdisciplinary practise of Religion and Gender have made us revise our original outline for the first issue. We decided to present a more modest opening which will be followed by a series of thematic issues of Religion and Gender in which the 
aforementioned 'grand questions' will appear one by one, receiving the multifaceted attention we want to pay them. These subjects will alternate with other themes that have been suggested by the members of our editorial network. This first issue, therefore, does not attempt to cover all the core issues that are at stake in our field, but it does reflect in an exemplary way the profile and characteristics of this journal. It also represents the wide scope and the varied nature of the critical issues in the study of religion and gender that are identified by the members of our editorial and advisory boards.

In their statements they insist on researching the grand questions stated above, but they also remind us to acknowledge and support the internal wrestling with and the particular appropriations of gender criticism that take place in disciplines such as Islam studies, Jewish studies, history of Christianity, art history, medical anthropology, psychology and anthropology of religion and the study of New Religious Movements. They call for the use of a more sophisticated and more up-to-date critical theory, while they also envision creative clusterings of established research perspectives to attend to issues that have a long history in gender studies in religion and are in constant need of watchful investigation - for example, 'the relative power of women in expressing their religion, in claiming rights of interpretation of holy texts, and in obtaining leadership positions.' They call for in-depth research into phenomena that point to repatriarchalization of religion(s): 'Signs of the resurgence of patriarchy as religious mandate are evident in all of the world's religions and in all Christian churches.' Nevertheless they also warn explicitly not to 'religionize' too easily: '[I]n many societies, poverty and class issues are more decisive factors for obstructing change, development, and empowerment of women than religion or theological suppositions and beliefs.'

\section{Entry Into the First Issue}

With such an amount of critical issues proposed by the members of our advisory and editorial boards, we think the moment has arrived to open this new forum of debate and to organize the publication of many future issues of Religion and Gender. We hope that this online journal will attract and connect many researchers from a great variety of contexts, disciplines, generations, and interests, who are as excited as we are to discuss 'religion and gender' in a systematic and interdisciplinary perspective. The fact that we have already found so many outstanding scholars in this field willing to commit themselves to this journal in its initial phase is not only a great 
support, but also shows that the hopes and expectations we have for this journal are recognized and shared.

It opens with a contribution of Margaret D. Kamitsuka, 'Feminist Scholarship and Its Relevance for Political Engagement: The Test Case of Abortion in the US.' Kamitsuka raises the crucial question of whether the political origins and edges of the formative phases and initial approaches to gender, sexuality, and religion still reverberate in contemporary sophisticated gender-critical analyses in theology and religious studies. She explores how gender studies, after going through major changes in academe, including in religious studies, might keep relevance to ongoing feminist political engagement. The issue of abortion in the US forms her test case. She shows how three formative feminist principles (women's experience as feminism's starting point, the personal is political, and identity politics) have shaped approaches to the abortion issue for feminist scholars in religion, and argues that ongoing critique, new theoretical perspectives, and attentiveness to subaltern voices are necessary for these foundational feminist principles to keep pace with fast-changing and complex societal dynamics relevant to women's struggles for reproductive health and justice. The essay concludes by proposing 'natality' (Hannah Arendt, Grace Jantzen) as a helpful concept for future feminist theological and ethical thinking on the subject.

The second contribution discusses an important new movement in continental philosophy, labelled with such names as 'new materialism' (Karen Barad) and 'speculative realism' (Jane Bennett), and explores its relevance for the study of religion and gender. In 'Vital New Matters: The Speculative Turn in the Study of Religion and Gender', Paul Reid-Bowen starts with providing an introduction to this turn toward metaphysics, realism and speculative philosophy. It stands in sharp contrast with the antirealist and correlationist traditions that have held sway since Kant's Copernican Revolution in 1781. According to Reid-Bowen, the study of religion and gender has been extensively shaped by the antirealist legacy of Kant, and he claims that there are good reasons for taking account of the new 'speculative turn'. In this essay, he introduces two examples from the leading exponent of this turn, speculative realism, discussing the work of Jane Bennett and Graham Harman, and considering some provisional notes about applying their stances to the gender-critical turn in the study of religion. In the last part of this article research notes on the current state of the Goddess movement serve as a test case for the introduction of an object-oriented ontology into religious and gender studies. 
The third essay, 'Implications of Queer Theory for the Study of Religion and Gender: Entering the Third Decade', is written by Claudia Schippert. It focuses on the conceptual and contextual shifts that queer theoretical work is contributing to academic discourse and to scholarship in religion and gender. Speaking primarily from a North American context, this essay wants to foreground in particular the impact of current queer studies at the intersection with postcolonial studies. Schippert argues that these recent approaches provide sets of particularly critical and productive challenges with far-reaching implications for the study of gender and religion, certainly in the ways it has been constituted in its modern academic version. In her essay Schippert reviews important recent themes in queer theoretical scholarship in the light of queer studies entering their third decade (M. Wilcox, J. E. Muñoz, J. R. Jakobsen and A. Pellegrini, L. Duggan). She suggests that among its implications are a more undisciplined study of religion (and secularism) that takes seriously shifts resulting from transnational and diasporic queer scholarship as well as shifts in conceptions of agency and resistance resulting from analyses and critique of homonormative positions, and that can intervene critically in homonationalism and Islamophobia.

The fourth essay is contributed by Burkhard Scherer, 'Macho Buddhism: Gender and Sexualities in the Diamond Way.' This article seeks to explore the significance of gender and sexualities studies for the critical study of Western Tibetan Buddhist movements. Scherer departs from the observation that while these movements have mostly been described as bourgeois and puritanical in previous scholarship, Ole Nydahl's convert lay Karma Kagyu Buddhist movement, the Diamond Way, stands out for its apparent hedonistic style. Scherer puts this observation in the wider context of issues of continuity and change during the transition of Tibetan Buddhism from Asia to the West. While analysing views on and performances of gender, sexual ethics and sexualities - both diachronically through textual-historical source and discourse analysis and synchronically through qualitative ethnography - he demonstrates how the approaches of contemporary gender and sexualities studies serve as a way to question the Diamond Way Buddhism's location in the 'tradition vs modernity' debate. Nydahl's pre-modern gender stereotyping, the hetero-machismo of the Diamond Way and the mildly homophobic tone and content of Nydahl's teaching are interpreted in light of Indian and Tibetan Buddhist sexual ethics and traditional Tibetan cultural attitudes on sexualities. By excavating the emic genealogy of Nydahl's teachings, the article suggests that Nydahl's and the Diamond Way's view on and performance of gender 
and sexualities are consistent with their propagation of convert Buddhist neo-orthodoxy.

The fifth and last essay, 'Male Headship as Male Agency: An Alternative Understanding of a "Patriarchal" African Christian Discourse on Masculinity', is written by Adriaan van Klinken. This article aims to scrutinize the concept and the discursive framework of patriarchy as a critical tool in the study of men, masculinities and religion and in particular in African theological scholarship on religion and masculinity. The article is based on fieldwork in Christian churches in Sub-Saharan Africa and studies the finding that in this context 'male headship' is a defining notion of masculinity. The central question Van Klinken poses is how religious discourses on masculinity that affirm male headship can be understood from a gender-critical perspective. A review of recent scholarship on masculinities and religion shows that references to male headship are commonly interpreted in terms of male dominance. However, a case study of sermons in a Zambian Pentecostal church elucidates that discourse on male headship can be far more complex and may even contribute to a transformation of masculinities. Van Klinken's main argument is that a monolithic concept of patriarchy hinders a nuanced analysis of the meaning and function of male headship in local contexts. Relying on the work of cultural anthropologist Saba Mahmood, Van Klinken suggests that in some discursive and practical settings male headship can be understood in terms of agency.

On behalf of the editing team, I would like to conclude this opening with the wish that the reader will enjoy reading the first issue of Religion and Gender, and the many issues to come.

\section{Acknowledgements}

Religion and Gender gratefully thanks all who have generously contributed to the establishment of the journal and the launch of this first issue. In particular Religion and Gender acknowledges the following individuals and organizations:

The members of the International Editorial and Advisory Boards for their enthusiastic response to the invitation to join and support this new ejournal. In particular, thanks to those members who have contributed positioning papers on the journal's profile statement: Barbara Baert, Angela Berlis, Maaike de Haardt, Birgit Heller, Stephen Hunt, Willy Jansen, Katharina von Kellenbach, Björn Krondorfer, Judith Plaskow, 
Melissa Raphael, Anne Sophie Roald, Burkhard Scherer and Susan Sered.

Sarah Bracke, Annika den Dikken and Wietske de Jong for their contributions made in the early stages of the establishment of Religion and Gender.

Melissa Raphael for her editorial input during the preparations of the first issue of Religion and Gender.

The Netherlands Organisation for Scientific Research (NWO) for supporting Religion and Gender financially as part of the Incentive Fund Open Access Journals in the Humanities.

Christine de Pisan Foundation and IWFT Expertise Network on Religion and Gender for the moral and financial support in the establishment of the journal.

Tilburg University Library, in particular Eric van den Akker and Marian Papavoine, for accepting and supporting Religion and Gender as a pilot open access project in the initial stage of the establishment of the journal.

Igitur Publishing Services, Utrecht University Library, in particular Marnix van Berchum, Inge Werner, Erika Manten, Anja Bastenhof, Joost van Gemert and Anja Firet, for supporting Religion and Gender in a crucial stage and for their assistance of the editors in preparing the launch of the journal.

Inez van der Spek for her commitment as a copyeditor to improve the texts published in Religion and Gender.

Franneke Hoeks, Zinstreling Design, for designing the fresh, colourful and recognizable outlook of Religion and Gender. 